\title{
APPRAISAL OF PROFESSIONAL AND ETHICAL CONDUCT OF HEALTHCARE PROVISIONS IN PRISONS IN NIGERIA: PERSPECTIVES OF PATIENT INMATES.
}

\author{
Ochonma, O.G, PhD \\ Department of health administration and management, Faculty of health sciences and technology, \\ University of Nigeria, Enugu Campus, Enugu, Nigeria. Phone: +234-8068093922; Email: \\ ogbonnia.ochonma@unn.edu.ngCorresponding author
}

\section{Chijioke, O.U, MSc}

Department of health administration and management, Faculty of health sciences and technology, University of Nigeria, Enugu Campus Enugu, Nigeria. Phone: +234-8033423111; Email: udunma.chijioke@unn.edu.ng

\section{Okoronkwo, I.L, PhD}

Department of Nursing Sciences, Faculty of Health Sciences and Technology, University of Nigeria, Enugu Campus. Phone: +234-8063581297 Email: Ijeoma.okoronkwo@unn.edu.ng

\section{Nwodoh, Chijioke Oliver, MSc}

Department of Nursing Sciences, Faculty of Health Sciences and Technology, College of Medicine, University of Nigeria, Enugu Campus, Enugu State, Nigeria. Phone:+234-8035452419.

chijioke.nwodoh@unn.edu.ng; chijioke.nwodoh@gmail.com

\begin{abstract}
Professional and Ethical rules for health care professionals in prisons are amply and clearly defined in rules, resolutions, declarations, and recommendations by the United Nations and other international and local bodies. The application of these rules in prisoner healthcare treatment has not been ascertained in Nigerian and as such prompted this study.This was a cross-sectional study conducted at three prisons in Enugu, Oji River and Ibite-Olo all in Enugu State of Nigeria. Included in the study were all the prisoners who at one time or the other had used or presently using prison healthcare services as patients. The overall assessment of professionals' conduct for the three prisons and all the prisons put together shows that in Enugu prison and Oji River prison, the mean assessment score for providers was significantly above average while in Ibite-Olo prison, the mean assessment score was below average though not significant. For all the prisons, the mean assessment score was significantly above average. In conclusion, each prison differed from the other on the assessment of professionals' conduct but overall the assessment was a little above overage for the three prisons put together. Providers of healthcare services in the prison need to be sensitized to the special healthcare needs of the prison patient population. Some of the standard ethical and professional rules in prison regarding healthcare provision will require that: Regardless of the circumstances, the ultimate goal of health care staff in prisons must remain the welfare and dignity of the patients. The results of medical examinations and tests undertaken in prison with consent as part of clinical care must be treated with the same respect for confidentiality as is normal under ethics in medical practice.
\end{abstract}

Keywords: Professional/ethical conduct, healthcare providers, prisons, patient inmates' perspectives. 


\section{Background}

Professional and Ethical rules for health care professionals in prisons are amply and clearly defined in rules, resolutions, declarations, and recommendations by the United Nations (UN) [Pont et al., 2012; UN Standard minimum rules, 2011; UN Resolution 37/194, 2011; UN Body of principles for the protection of all persons under any form of detention, 2011; UN Istanbul protocol manual on the effective investigation and documentation, 2011; 1999; the World Medical Association, 2011; the International Council of Nurses, 2011; Physicians for Human Rights, 2011; and Penal Reform International, 2001]. A few national codes also relate to health care matters in prison [Pont et al, [2012]According to these documents, the sole task of health care professionals working in prisons is the care of physical and mental health of the prisoners by acting as the private caregiver to the prisoners and observing the 7 essential principles of medical care in prison as quoted in the standards of the European Committee for Prevention of Torture (free access to medical care, equivalence of prison health care and community health care, confidentiality, patients' consent, preventive health care. All of these tasks, it is recommended must be performed with complete loyalty to the prisoners; medical activities not in the interest of prisoners should not be undertaken by professionals who provide health care to prisoners, as stated clearly in principle 3 of the UN resolution on principles of medical ethics relevant to the role of health personnel in prison.

However, health care professionals in prisons face extraordinary ethical challenges: prisoners, who cannot choose their care provider and who are fully dependent on the health care provided to them, are a vulnerable population, as demonstrated by the many exploitations, abuses, and violations of their human rights in the past [Pont et al., 2012].

\section{Violations of Prisoners' Right within the principles of Medical Ethics}

Despite this international body of ethical documents, health care professionals working in prisons continue to be at risk for violating principles of medical ethics [Pont et al., 2012; Physicians for Human Rights and School of Public Health and Primary HealthCare, 2002], and prison authorities, representatives of states, and even scholars of criminal law ignore or override them time and again. The most spectacular violations in recent history that were brought before the public and widely discussed involved force-feeding of hunger strikers by healthcare professionals [Pont et al., 2012; Annas et al., 2006; Zwangsernährung, 2010], participation in carrying out the death penalty [Pont $e t a l, 2012$; Gawande, 2006], and complicity in torture [Pont et al., 2012; Lifton, 2004; Iacopino et al., 2011]. However, many subtle, much less spectacular situations in daily prison life cause health care professionals to forsake loyalty to their patients, often unwittingly or by failing to scrutinize routine procedures, decrees, or laws against the standards of medical ethics and human rights: The medical examination on admission of prisoners is of indisputable importance for the detection and treatment of health disorders, particularly those incompatible with imprisonment. However, the healthcare professional who is to care for the health of the prisoner as a private caregiver [Pont et al., 2012; European Committee for the Prevention of Torture and Inhuman, 2011; Penal Reform International, 2011] 
should not issue certifications that prisoners are fit for imprisonment-a professional act that clearly is outside the principles of medical ethics and hardly ever fosters a trustful relationship with the patient [Pont et al., 2012].

\section{Restraints limiting the administration of healthcare in the prison}

A range of policies, procedures, and methods are implemented to secure prisoners and protect society. These include: physical barriers such as the use of perimeter walls and control of entry and exit points; organisational policies, including the security classification of prisoners, and politically driven policies such as "getting tough on crime" through legislation [White et al., 2014; Weiskopf, 2005]. Organisational and political practices and policies, both formal and informal, also impact on the delivery of health care to prisoners and on health care practitioners charged with caring for incarcerated patients [White et al., 2014; Weiskopf, 2005]. This lack of liberty, which characterises correctional contexts, inevitably impacts on patients, the delivery of health care, and on health care practitioners [White et al., 2014; Weiskopf, 2005].

The inmate's self is also violated in physical ways - "the boundary that the individual places between his being and the environment is invaded and the embodiments of self-profaned" [White et al., 2014; Goffman, 1961]. Prisoners are never alone and always watched. Private and potentially embarrassing medical information about themselves is available to the prison staff. They can be subjected to strip searches and medical examinations, and they have little choice over their food, their accommodation, cell or dormitory partners, and where they are imprisoned. This lack of agency and physical threat add to the process of mortification [White et al., 2014].

\section{The confusing duality of providers' healthcare role and infringements on inmates' care}

Doctors working in a prison are frequently torn between different loyalties. Their primary duty is to protect and promote the health of detainees and to ensure that the detainees receive the best possible care [Health in prisons. A WHO guide to the essentials in prison health, 2007]. This duty may, however, conflict with other priorities, notably those of the prison administration. In practice, the health care team is frequently obliged, despite its reticence, to take into account issues of order and security [Health in prisons. A WHO guide to the essentials in prison health, 2007]. Conversely, the security personnel may find it difficult to accept attitudes, beliefs and behaviour of health care staff that they perceive to conflict with prison rules and regulations [Health in prisons. A WHO guide to the essentials in prison health, 2007].

\section{The right to refuse treatment by patient inmate}

The courts have long recognized that a competent person possesses the right to refuse treatment. Although debate continues regarding the true scope of this right, it is widely acknowledged as a byproduct of the doctrine of informed consent, which defines as a tort the performance of any medical procedure without patient consent. The court held that: Every human being of adult years and sound mind has a right to determine what shall be done with 
his own body; and a surgeon who performs an operation without his patient's consent commits an assault, for which he is liable in damages [Schloendorff v. Society of New York Hospital, 105 N.E. 92, 93 N.Y, 1914; Frederick et al, 1999]. Some courts have found the right to derive from an elusive liberty interest or right of privacy, and they have come to apply the doctrine to grant judicial sanction even to one's refusal of a well-meaning attempt to save his life [Schloendorff v. Society of New York Hospital, 105 N.E. 92, 93 N.Y, 1914; Natanson v. Kline, 350 P.2d 1093, 1960]. It may be fair to say that the rapid emergence of advanced medical technology over the last two decades has provided the main impetus for the modern so-called right-to-die cases (having given medical professionals the ability to sustain life well beyond its natural barriers of time and physics) [Schloendorff v. Society of New York Hospital, 105 N.E. 92, 93 N.Y, 1914]. Perhaps the most widely noted of the recent cases is Cruzan v. Director [Schloendorff v. Society of New York Hospital, 105 N.E. 92, 93 N.Y, 1914; Cruzan v. Director, Missouri Department of Health, 497 U.S. 261, 1989] in which the physician has an ethical obligation to help the patient make choices from among the therapeutic alternatives consistent with good medical practice.

\section{Methods}

\section{Study area}

The study was conducted in Enugu state, South-east Nigeria. The State has a population of about 3.3 million people (2006 census) of whom 95\% are Igbo [SMOH, Enugu State, 2011]. Administratively, the State is divided into 17 Local Government Areas (LGAs) and 3 senatorial zones [Ezuma, 2012]. Enugu state shares its boundaries with five states, four in the North and one in the South [Enugu State, 2004]. Urban dwellers are mostly civil servants, traders, transporters or artisans while rural dwellers are mainly subsistence farmers or petty traders [Okoli et al., 2011]. A small proportion of the population is engaged in manufacturing activities although the state has a well-developed commercial and financial centre [Onwujekwe et al., 2010].

\section{Data collection procedure and Ethical clearances}

Those included in the study were all the prison patient in-mates who had previously used the prison healthcare services and those using the services at the time of our study. Ethical approval for the research was obtained from a local ethical clearance committee (University of Nigeria ethical and review committee). Using an originally developed and validated questionnaire [Ogbonnia et al., 2016] data was collected from the patients on their perceptions of the professional and ethical conduct of healthcare providers during their encounter.

\section{Method of Data Analysis}

Both descriptive and inferential statistics were used in the analysis of the work. The descriptive statistics- frequency and percentage were used to summarize the items on demography of the 
prison patients and items on assessment of professional conducts of healthcare providers. The inferential statistics- One Sample t-test, Independent Samples t-test and One Factor ANOVA for Between-Groups were used. The One Sample t-test was used to compare assessment scores to an average expected score, the Independent Sample t-test was used to compare assessment scores of two independent groups while the ANOVA was used to compare assessment scores of more than two independent groups. In analysis involving ANOVA, the Welch Statistic was reported in all cases were equality of variance assumption was violated. The normality assumption which necessitated these parametric tests was met. The assessment score used for these tests were generated by summing the responses on the items on assessment accordingly. The expected average for the One Sample t-test is a midpoint of the possible assessment scores. A logistic regression was also performed on the data. The demographic data and the prison served as the predictors while the assessment score categorized into binary variable served a predicted variable. Statistical decisions were made at 0.05 level of significance while the statistics were done using the IBM SPSS version 20.

\section{Results}

Table 1: Socio-demographic Data of the Inmates

\begin{tabular}{|c|c|c|c|c|c|}
\hline & & & ividual Pris & & All Prisons \\
\hline & & Enugu & Ibite-Olo & Oji River & \\
\hline & $\leq 20$ years & $6(6.5)$ & $3(14.3)$ & $2(5.4)$ & $11(7.3)$ \\
\hline & 21-30 years & $44(47.8)$ & $14(66.7)$ & $17(45.9)$ & $75(50.0)$ \\
\hline Age & $31-40$ years & $23(25.0)$ & $4(19.0)$ & 14(37.8) & $41(27.3)$ \\
\hline & $41-50$ years & $11(12.0)$ & $0(0.0)$ & $2(5.4)$ & $13(8.7)$ \\
\hline & $51+$ years & $8(8.7)$ & $0(0.0)$ & $2(5.4)$ & $10(6.7)$ \\
\hline & Total & $92(100.0)$ & 21(100.0) & $37(100.0)$ & $150(100.0)$ \\
\hline Sy & Male & 77(84.6) & $21(100.0)$ & $36(100.0)$ & $134(90.5)$ \\
\hline Sex & Female & $14(15.4)$ & $0(0.0)$ & $0(0.0)$ & $14(9.5)$ \\
\hline & Total & $91(100.0)$ & $21(100.0)$ & $36(100.0)$ & $148(100.0)$ \\
\hline & $\leq 6 \mathrm{mths}$ & $27(29.3)$ & $3(15.8)$ & $10(27.0)$ & $40(27.0)$ \\
\hline Length of jail & $7 \mathrm{mths}-2 \mathrm{yrs}$ & $33(35.9)$ & $10(52.6)$ & $8(21.6)$ & $51(34.5)$ \\
\hline service & $3-7 \mathrm{yrs}$ & $23(25.0)$ & $5(26.3)$ & 19(51.4) & $47(31.8)$ \\
\hline & $8+y r s$ & $9(9.8)$ & $1(5.3)$ & $0(0.0)$ & $10(6.8)$ \\
\hline & Total & $92(100.0)$ & 19(100.0) & $37(100.0)$ & $148(100.0)$ \\
\hline Highest & No school & $0(0.0)$ & $4(19.0)$ & $0(0.0)$ & $4(2.7)$ \\
\hline educational & Primary & $4(4.5)$ & $5(23.8)$ & $4(10.8)$ & $13(8.9)$ \\
\hline qualification & Secondary & $47(53.4)$ & $11(52.4)$ & 14(37.8) & $72(49.3)$ \\
\hline
\end{tabular}




\begin{tabular}{llcccc}
\hline \hline & Tertiary & $37(42.0)$ & $1(4.8)$ & $19(51.4)$ & $57(39.0)$ \\
& Total & $88(100.0)$ & $21(100.0)$ & $37(100.0)$ & $146(100.0)$ \\
& & & & \\
& Student & $33(36.7)$ & $2(10.5)$ & $12(33.3)$ & $47(32.4)$ \\
& Govt. employee & $13(14.4)$ & $2(10.5)$ & $2(5.6)$ & $17(11.7)$ \\
& Trading & $18(20.0)$ & $4(21.1)$ & $9(25.0)$ & $31(21.4)$ \\
& Self employed & $22(24.4)$ & $5(26.3)$ & $9(25.0)$ & $36(24.8)$ \\
& Unemployed & $2(2.2)$ & $6(31.6)$ & $3(8.3)$ & $11(7.6)$ \\
& Others & $2(2.2)$ & $0(0.0)$ & $1(2.8)$ & $3(2.1)$ \\
& Total & $90(100.0)$ & $19(100.0)$ & $36(100.0)$ & $145(100.0)$ \\
\hline
\end{tabular}

Table 1 displays the demographic data of the prison inmates. In age, majority of the inmates were between 21-30 years: Enugu prison (47.8\%), Ibite-Olo prison (66.7\%) and Oji River prison $(45.9 \%)$ and all the prisons put together $(50.0 \%)$. Males were predominant in Enugu prison (84.6\%), Ibite-Olo prison (100.0\%) and Oji River prison (100.0\%), and in all the prisons put together (90.5\%). In length of jail service, Enugu prison (35.9\%) and Ibite-Olo prison (52.6\%), and all the prisons put together (34.5\%) had more inmates that have served 7 months -2 years while Oji River prison had more of those that have served 3-7 years (51.4\%). Inmates with secondary education were predominant in Enugu prison (53.4\%) and Ibite-Olo prison (52.4\%), and all the prisons put together $(49.3 \%)$ while those with tertiary education were predominant in Oji River (51.4\%). In Enugu prison (36.7\%) and Oji River prison (33.3\%) and all the prisons put together $(32.4 \%)$, students were most while in Ibite-Olo prison, the unemployed were most $(31.6 \%)$.

\section{Table 2: Assessment of Professional Conduct of Healthcare Providers: Patients' Perspectives}

\begin{tabular}{lcccc}
\hline & \multicolumn{3}{c}{ Individual prisons } & All prisons \\
Areas of Professional Conduct & Enugu & Ibite-Olo & Oji River & \\
\hline $\begin{array}{l}\text { Observance of the principle of informed consent } \\
\text { including the right of patients to refuse services }\end{array}$ & $2.68 \pm 0.97$ & $1.43 \pm 0.98^{*}$ & $2.86 \pm 0.99$ & $2.54 \pm 1.08$ \\
$\begin{array}{l}\text { Observance of dignity, privacy and autonomy of } \\
\text { patients during treatment/service }\end{array}$ & $2.68 \pm 1.12$ & $1.75 \pm 1.07^{*}$ & $3.14 \pm 1.05$ & $2.66 \pm 1.17$ \\
$\begin{array}{l}\text { Observance of clear and appropriate professional } \\
\text { boundaries during service provision }\end{array}$ & $2.79 \pm 0.99$ & $3.71 \pm 0.78$ & $3.39 \pm 0.84$ & $3.08 \pm 0.99$ \\
$\begin{array}{l}\text { Observance of equitable treatment regardless of } \\
\text { gender and person }\end{array}$ & $2.76 \pm 1.02$ & $3.70 \pm 0.80$ & $3.06 \pm 1.00$ & $2.97 \pm 1.03$ \\
$\begin{array}{l}\text { Observance of individualized service during } \\
\text { examination taking into account patients' physical } \\
\text { and emotional needs, values and background }\end{array}$ & $2.60 \pm 1.04$ & $2.62 \pm 1.40$ & $3.03 \pm 1.07$ & $2.71 \pm 1.11$ \\
& & & & \\
\end{tabular}


Observance of the principle of confidentiality of information acquired through professional contact

Timely completion of examination and in response to patients' needs

Providers' explanation of experience, expectations, knowledge and procedure to patient before service

Competence in service performance

Ability to take personal responsibility, use discretion and judgment in a manner that ensured patient's best service outcome

Competence and limitations disclosure where appropriate in the process of service provision

Ability to act in patients' best interest during contact and service delivery

Exercise of professional duty of care by holding up patients' best interest in service delivery

Ability to understand the limits of one's practice and when to seek advice or refer to another professional

Ability to exercise the need to engage patient in planning and evaluating diagnostics, treatments and interventions to meet patients' health needs and goals

Ability to make appropriate referrals as the need be in the process of care and examination

Demonstration of effective and appropriate skills in communicating information, advice, instruction and professional opinion

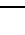

\begin{tabular}{|c|c|c|c|}
\hline $2.94 \pm 1.06$ & $2.85 \pm 1.46$ & $3.24 \pm 1.06$ & $3.01 \pm 1.12$ \\
\hline $2.87 \pm 1.06$ & $2.86 \pm 1.24$ & $3.06 \pm 0.95$ & $2.91 \pm 1.06$ \\
\hline $2.66 \pm 1.07$ & $2.45 \pm 1.28 *$ & $2.72 \pm 1.14$ & $2.64 \pm 1.11$ \\
\hline $2.80 \pm 1.11$ & $2.19 \pm 1.29 *$ & $3.08 \pm 1.00$ & $2.78 \pm 1.13$ \\
\hline $2.62 \pm 1.08$ & $2.14 \pm 1.15^{*}$ & $3.03 \pm 0.93$ & $2.66 \pm 1.08$ \\
\hline $2.83 \pm 1.08$ & $2.20 \pm 1.28 *$ & $2.86 \pm 1.06$ & $2.75 \pm 1.12$ \\
\hline $2.73 \pm 1.09$ & $2.90 \pm 1.18$ & $3.22 \pm 0.95$ & $2.87 \pm 1.08$ \\
\hline $2.69 \pm 1.03$ & $2.43 \pm 1.47^{*}$ & $3.08 \pm 1.04$ & $2.75 \pm 1.11$ \\
\hline $2.89 \pm 1.02$ & $1.43 \pm 0.98 *$ & $3.32 \pm 0.82$ & $2.79 \pm 1.13$ \\
\hline $2.60 \pm 1.11$ & $1.52 \pm 0.98^{*}$ & $2.92 \pm 1.21$ & $2.52 \pm 1.20$ \\
\hline $2.76 \pm 1.01$ & $1.48 \pm 0.98 *$ & $2.84 \pm 1.14$ & $2.59 \pm 1.13$ \\
\hline $2.68 \pm 1.07$ & $1.86 \pm 1.15^{*}$ & $2.81 \pm 1.02$ & $2.59 \pm 1.11$ \\
\hline
\end{tabular}

$2.85 \pm 1.46+3$

\footnotetext{
* implies professional conducts assessed below average (2.5)
}

Table 2 displays the prison patients' assessment of professional conducts of healthcare providers. In Enugu prison, there was an above average compliance to all the listed professional conduct; however, the prominent ones include: observance of the principle of confidentiality of information acquired through professional conduct (2.94 \pm 1.06$)$, ability to understand the limits of his/her practice and when to seek advice or refer to another professional $(2.89 \pm 1.02)$, timely completion of examination and in response to patients' needs $(2.87 \pm 1.06)$, competence and limitations disclosure where appropriate in the process of service provision $(2.83 \pm 1.08)$ and competence in service performance $(2.80 \pm 1.11)$. 
In Ibite-Olo prison, professional conducts such as observance of the principle of informed consent including the right of patients to refuse services $(1.43 \pm 0.98)$, ability to understand the limits of one's' practice and when to seek advice or refer to another professional (1.43 \pm 0.98$)$, ability to make appropriate referrals as the need be in the process of care and examination (1.48 \pm 0.98$)$, ability to exercise the need to engage patient in planning and evaluating diagnostics, treatments and interventions to meet patient's health needs and goals $(1.52 \pm 0.98)$, observance of dignity, privacy and autonomy of patients during treatment/service $(1.75 \pm 1.07)$ and demonstration of effective and appropriate skills in communicating information, advice, instruction and professional opinion $(1.86 \pm 1.15)$ were very lightly complied to. However, in observance of clear and appropriate professional boundaries during service provision $(3.71 \pm 0.78)$ and observance of equitable treatment regardless of gender and person (3.70 \pm 0.80$)$, there was a very high level of compliance.

In Oji-River prison, there was an above average compliance to all the listed professional conducts; however the prominent ones include: observance of clear and appropriate professional boundaries during service provision ( $3.39 \pm 0.84)$, ability to understand the limits of one's practice and when to seek advice or refer to another professional (3.32 \pm 0.82$)$, observance of the principle of confidentiality of information acquired through professional contact (3.24 \pm 1.06$)$, ability to act in patients' best interest during contact and service delivery (3.22 \pm 0.95$)$ and observance of dignity, privacy and autonomy of patients during treatment/service $(3.14 \pm 1.05)$.

In general, for the three prisons put together, four most complied professional conducts were observance of clear and appropriate professional boundaries during service provision (3.08 \pm 0.99$)$, observance of the principle of confidentiality of information acquired through professional contact (3.01 \pm 1.12$)$, observance of equitable treatment regardless of gender and person $(2.97 \pm 1.03)$ and timely completion of examination and in response to patients' needs (2.91 \pm 1.06$)$. No professional conduct was complied with below average.

Table 3: Overall Assessment of Professional Conduct of Healthcare Providers

\begin{tabular}{lcccccc}
\hline Prison & $\mathrm{n}$ & $\mathrm{M} \pm \mathrm{SD}$ & Expected average & $\mathrm{t}$ & $\mathrm{df}$ & $\mathrm{p}$-value \\
\hline Enugu & 67 & $46.30 \pm 11.00$ & 42.5 & 2.827 & 66 & .006 \\
Ibite-Olo & 19 & $39.79 \pm 12.09$ & & -.978 & 18 & .341 \\
Oji River & 32 & $52.88 \pm 9.72$ & & 6.037 & 31 & $<.001$ \\
All prisons & 118 & $47.03 \pm 11.57$ & & 4.256 & 117 & .000 \\
\hline
\end{tabular}

Table 3 displays the overall assessment of professional conducts of healthcare providers for the different prisons and all prisons put together. In Enugu prison $(46.30 \pm 11.00, \mathrm{p}=.006)$ and Oji River prison $(52.88 \pm 9.72, \mathrm{p}<.001)$, the mean assessment score was significantly above average while in Ibite-Olo prison, the mean assessment score was below average though not significant $(39.79 \pm 12.09, \mathrm{p}=.341)$. For all prisons, the mean assessment score was significantly above average $(47.03 \pm 11.57, \mathrm{p}<.001)$. This implies that the professional conduct of healthcare 
providers in Enugu and Oji-River prison was above average while that of Ibite-Olo was average.

Table 4: Professional Conduct Assessment Comparison between Prisons

\begin{tabular}{lccccc}
\hline Prisons & $\mathrm{n}$ & $\mathrm{M} \pm \mathrm{SD}$ & $\mathrm{df}$ & $\mathrm{F}$ & $\mathrm{p}$-value \\
\hline Enugu & 67 & $46.30 \pm 11.00$ & 2,115 & 9.024 & $<.001$ \\
Ibite-Olo & 19 & $39.79 \pm 12.09$ & & & \\
Oji River & 32 & $52.88 \pm 9.72$ & & & \\
\hline
\end{tabular}

Table 4 displays the comparison between prisons on professional conduct assessment. Oji-River prison had highest assessment score $(52.88 \pm 9.72)$, followed by Enugu prison $(46.30 \pm 11.00)$ while that of Ibite-Olo prison was least $(39.79 \pm 12.09)$. The comparison revealed a significant difference between the prisons, $\mathrm{p}<.001$. A post-hoc test indicated that each prison differed from the other.

Table 5: Professional Conduct Assessment Comparison between Age Groups

\begin{tabular}{|c|c|c|c|c|c|c|}
\hline & & $\mathrm{n}$ & Mean & df & $\mathrm{F}$ & $p$-value \\
\hline \multirow[t]{5}{*}{ Enugu } & $\leq 20$ years & 4 & $47.50 \pm 6.40$ & 4,61 & .892 & .474 \\
\hline & $21-30$ years & 31 & $48.71 \pm 10.32$ & & & \\
\hline & $31-40$ years & 17 & $42.59 \pm 12.17$ & & & \\
\hline & $41-50$ years & 8 & $47.00 \pm 13.13$ & & & \\
\hline & $51+$ years & 6 & $45.17 \pm 9.20$ & & & \\
\hline \multirow[t]{3}{*}{ Ibite-Olo } & $\leq 20$ years & 3 & $40.00 \pm 24.25$ & $2,4.135$ & $.330^{*}$ & .737 \\
\hline & $21-30$ years & 12 & $38.58 \pm 10.23$ & & & \\
\hline & $31-40$ years & 4 & $43.25 \pm 8.88$ & & & \\
\hline \multirow[t]{4}{*}{ Oji River } & $<20$ years & 2 & $58.00 \pm 2.83$ & 3,28 & .920 & .444 \\
\hline & $21-30$ years & 14 & $53.29 \pm 8.93$ & & & \\
\hline & $31-40$ years & 13 & $53.54 \pm 11.24$ & & & \\
\hline & $41+$ years & 3 & $44.67 \pm 7.23$ & & & \\
\hline \multirow[t]{5}{*}{ All prisons } & $<20$ years & 9 & $47.33 \pm 14.56$ & 4,112 & .085 & .987 \\
\hline & 21-30 years & 57 & $47.70 \pm 11.06$ & & & \\
\hline & $31-40$ years & 34 & $46.85 \pm 12.39$ & & & \\
\hline & $41-50$ years & 10 & $45.70 \pm 11.90$ & & & \\
\hline & $51+$ years & 7 & $46.29 \pm 8.90$ & & & \\
\hline
\end{tabular}

* Welch Statistics computed due to equality of variance assumption violation

Table 5 displays the comparison between age groups on professional conduct assessment. In Enugu prison $(\mathrm{p}=.474)$, Ibite-Olo prison $(\mathrm{p}=.737)$ and Oji River prison $(\mathrm{p}=.444)$, there was no 
significant assessment difference between groups, and likewise for all prisons $(\mathrm{p}=.987)$. This implies that the assessment on professional conduct of healthcare providers was the same for the different age groups.

Table 6: Professional Conduct Assessment Comparison between Sex Groups

\begin{tabular}{llccccc}
\hline \multirow{2}{*}{ Enugu } & & $\mathrm{n}$ & Mean & $\mathrm{t}$ & $\mathrm{df}$ & $\mathrm{p}$-value \\
& Male & 54 & $46.26 \pm 11.43$ & -.706 & 63 & .483 \\
\multirow{5}{*}{ Ibite-Olo } & Female & 11 & $48.82 \pm 8.05$ & & & \\
& Male & 19 & $39.79 \pm 12.09$ & - & - & - \\
& Female & 0 & - & & & \\
\multirow{5}{*}{ Oji River } & Male & 32 & $52.88 \pm 9.72$ & - & - & - \\
& Female & 0 & - & & & \\
& & & & & & \\
\multirow{2}{*}{ All prisons } & Male & 105 & $47.10 \pm 11.85$ & -.467 & 114 & .641 \\
& Female & 11 & $48.82 \pm 8.05$ & & & \\
\hline
\end{tabular}

Table 6 displays the comparison between sex groups on professional conduct assessment. IbiteOlo and Oji River had no female patient participant. In Enugu prison, there was no significant assessment difference between males and females $(\mathrm{p}=.483)$, and likewise for all prisons $(\mathrm{p}=$ .641). This implies that the assessment on professional conduct of healthcare providers was the same for both male and female patients.

Table 7: Professional Conduct Assessment Comparison between Patients Grouped by Length of Jail Service

\begin{tabular}{llccccc}
\hline & & $\mathrm{n}$ & Mean & $\mathrm{df}$ & $\mathrm{F}$ & $\mathrm{p}$-value \\
\hline Enugu & $\leq 6 \mathrm{mths}$ & 20 & $47.55 \pm 9.78$ & 3,63 & 1.275 & .291 \\
& 7 mths -2 yrs & 25 & $46.80 \pm 10.02$ & & & \\
& $3-7$ yrs & 17 & $42.41 \pm 12.82$ & & & \\
& $8+$ yrs & 5 & $52.00 \pm 12.90$ & & & \\
Ibite-Olo & $\leq 6$ mths & 3 & $48.67 \pm 18.15$ & 2,15 & 1.029 & .381 \\
& 7 mths -2 yrs & 10 & $37.70 \pm 9.63$ & & & \\
& $* 3+$ yrs & 5 & $37.20 \pm 13.88$ & & & \\
Oji River & $\leq 6$ mths & 8 & $54.38 \pm 10.41$ & 2,29 & .121 & .887 \\
& 7 mths-2 yrs & 8 & $52.25 \pm 10.22$ & & & \\
& $3-7$ yrs & 16 & $52.44 \pm 9.72$ & & &
\end{tabular}




\begin{tabular}{llccccc}
\hline \hline All prisons & $\leq 6 \mathrm{mths}$ & 31 & $49.42 \pm 10.81$ & 3,113 & .705 & .551 \\
& 7 mths-2 yrs & 43 & $45.70 \pm 10.90$ & & & \\
& $3-7$ yrs & 37 & $46.32 \pm 12.78$ & & & \\
& $8+\mathrm{yrs}$ & 6 & $48.67 \pm 14.14$ & & & \\
\hline
\end{tabular}

* 8+ years had 1 participant thus was merged with 3-7 years

Table 7 displays the professional conduct assessment comparison between patients grouped by the length of jail service. In Enugu $(\mathrm{p}=.291)$, Ibite-Olo $(\mathrm{p}=.381)$ and Oji River $(\mathrm{p}=.887)$ prison, there was no significant assessment difference between groups, and likewise for all prisons $(\mathrm{p}=.551)$. This implies that the assessment of professional conduct of healthcare providers was the same for the different length of jail service groups.

Table 8: Professional Conduct Assessment Comparison between Educational Levels

\begin{tabular}{llccccc}
\hline & & $\mathrm{n}$ & Mean & $\mathrm{df}$ & $\mathrm{F}$ & $\mathrm{p}$-value \\
\hline Enugu & Primary & 4 & $46.75 \pm 12.09$ & 2,63 & .011 & .989 \\
& Secondary & 35 & $46.57 \pm 10.99$ & & & \\
& Tertiary & 27 & $46.19 \pm 11.37$ & & & \\
Ibite-Olo & No school & 3 & $47.00 \pm 21.00$ & 2,16 & 1.195 & .328 \\
& Primary & 5 & $33.80 \pm 7.56$ & & & \\
& *Secondary\& tertiary & 11 & $40.55 \pm 10.85$ & & & \\
& & & & & & \\
Oji River & Primary & 4 & $43.75 \pm 3.30$ & 2,29 & 2.228 & .126 \\
& Secondary & 11 & $53.45 \pm 11.23$ & & & \\
& Tertiary & 17 & $54.65 \pm 8.82$ & & & \\
& & & & & & \\
All prisons & No school & 3 & $47.00 \pm 21.00$ & 3,113 & 2.021 & .115 \\
& Primary & 13 & $40.85 \pm 9.67$ & & & \\
& Secondary & 56 & $46.61 \pm 11.61$ & & & \\
& Tertiary & 45 & $49.56 \pm 11.05$ & & & \\
\hline
\end{tabular}

\section{*Tertiary had 1 participant thus mergedwith secondary}

Table 8 displays the comparison made between educational levels on professional conduct assessment. In Enugu $(p=.989)$, Ibite-Olo $(p=.328)$ and Oji River $(p=.126)$ prison, no significant assessment difference existed between levels. For all prisons put together, there was likewise no significant assessment difference between levels, $(p=.115)$. This implies that the educational levels had the same assessment score on professional conduct of healthcare providers. 
Table 9: Professional Conduct Assessment Comparison between Occupational Groups

\begin{tabular}{|c|c|c|c|c|c|c|}
\hline & & $\mathrm{n}$ & Mean & df & $\mathrm{F}$ & p-value \\
\hline \multirow[t]{6}{*}{$\overline{\text { Enugu }}$} & Student & 26 & $49.62 \pm 9.24$ & 5,61 & 1.069 & .386 \\
\hline & Govt. employee & 9 & $41.00 \pm 12.74$ & & & \\
\hline & Trading & 12 & $43.58 \pm 10.41$ & & & \\
\hline & Self employed & 16 & $46.31 \pm 13.35$ & & & \\
\hline & Unemployed & 2 & $43.50 \pm 4.95$ & & & \\
\hline & Others & 2 & $46.00 \pm 4.24$ & & & \\
\hline \multirow[t]{4}{*}{ Ibite-Olo } & Govt. employee & 2 & $53.50 \pm 10.61$ & 3,13 & 2.378 & .117 \\
\hline & Trading & 4 & $38.25 \pm 5.97$ & & & \\
\hline & Self employed & 5 & $35.00 \pm 9.90$ & & & \\
\hline & Unemployed & 6 & $34.33 \pm 9.91$ & & & \\
\hline \multirow[t]{5}{*}{ Oji River } & Student & 11 & $54.00 \pm 8.15$ & 4,25 & .235 & .916 \\
\hline & Govt. employee & 2 & $57.00 \pm 9.90$ & & & \\
\hline & Trading & 7 & $50.86 \pm 10.95$ & & & \\
\hline & Self employed & 8 & $51.63 \pm 12.66$ & & & \\
\hline & Unemployed & 2 & $55.00 \pm 2.83$ & & & \\
\hline \multirow[t]{6}{*}{ All prisons } & Student & 38 & $51.37 \pm 9.35$ & 5,110 & 2.192 & .060 \\
\hline & Govt. employee & 13 & $45.38 \pm 13.18$ & & & \\
\hline & Trading & 23 & $44.87 \pm 10.58$ & & & \\
\hline & Self employed & 29 & $45.83 \pm 13.42$ & & & \\
\hline & Unemployed & 10 & $40.30 \pm 11.50$ & & & \\
\hline & Others & 3 & $51.67 \pm 10.26$ & & & \\
\hline
\end{tabular}

Table 9 displays the comparison made between occupational groups on professional conduct assessment. In Enugu ( $\mathrm{p}=.386$ ), Ibite-Olo $(\mathrm{p}=.117)$, Oji River $(\mathrm{p}=.916)$ prison, no significant assessment difference existed between groups, and likewise for all prisons $(p=.060)$. This implies that the different occupational groups had the same assessment score on professional conduct of healthcare providers. 
Table 10a: Logistic Regression Classification Table, Model Summary and Omnibus Test of Model Coefficients on Assessment of Professional Conduct of Healthcare Providers

\begin{tabular}{|c|c|c|c|c|c|c|c|c|c|}
\hline & Clas & ification & & & & del Sumr & nary & $\begin{array}{l}\text { Omnibus } \\
\text { Model Coe }\end{array}$ & $\begin{array}{l}\text { st of } \\
\text { cients }\end{array}$ \\
\hline & & $\begin{array}{r}\text { Pro } \\
\text { conduc }\end{array}$ & $\begin{array}{l}\text { ional } \\
\text { essment }\end{array}$ & $\begin{array}{c}\% \\
\text { Correct }\end{array}$ & $\begin{array}{c}-2 \log \\
\text { likelihood }\end{array}$ & $\begin{array}{c}\text { Cox \& } \\
\text { Snell R }\end{array}$ & $\begin{array}{c}\text { Nagelkerke } \\
\mathrm{R}^{2}\end{array}$ & $\chi^{2}$ & $\mathrm{p}$ \\
\hline & & Poor & Good & & & & & & \\
\hline Professional & Poor & 23 & 29 & 44.2 & & & & & \\
\hline $\begin{array}{l}\text { conduct } \\
\text { assessment }\end{array}$ & Good & 16 & 66 & 80.5 & 159.596 & .135 & .183 & $19.394 \quad 17$ & .306 \\
\hline Overall \% & & & & 66.4 & & & & & \\
\hline
\end{tabular}

\section{The cut value is .500}

Table 10b: Logistic Regression Model Coefficients on Assessment of Professional Conduct of Healthcare Providers

\begin{tabular}{lcccccccc}
\hline & B & S.E. & Wald & df & Sig. & Exp(B) & \multicolumn{2}{c}{$95 \%$ C.I.for EXP(B) } \\
& & & & & & & Lower & Upper \\
\hline Prison & & & 6.835 & 2 & .033 & & & \\
Ibite-Olo prison & -.260 & .686 & .143 & 1 & .705 & .771 & .201 & 2.960 \\
Oji River prison & 1.306 & .541 & 5.827 & 1 & .016 & 3.690 & 1.278 & 10.651 \\
Age & & & .835 & 4 & .934 & & & \\
$\leq 20$ years & -.511 & 1.298 & .155 & 1 & .694 & .600 & .047 & 7.633 \\
21-30 years & -.110 & .944 & .013 & 1 & .908 & .896 & .141 & 5.699 \\
31-40 years & -.466 & .903 & .266 & 1 & .606 & .628 & .107 & 3.687 \\
41-50 years & -.478 & 1.045 & .210 & 1 & .647 & .620 & .080 & 4.804 \\
Sex & .893 & .734 & 1.481 & 1 & .224 & 2.442 & .580 & 10.290 \\
Length of jail service & & & 1.042 & 3 & .791 & & & \\
$\leq 6$ months & -.297 & .940 & .100 & 1 & .752 & .743 & .118 & 4.694 \\
7 months -2 years & -.715 & .926 & .597 & 1 & .440 & .489 & .080 & 3.002 \\
3-7 years & -.618 & .901 & .470 & 1 & .493 & .539 & .092 & 3.155 \\
Education Level & & & 1.773 & 3 & .621 & & & \\
Primary & -1.374 & 1.924 & .510 & 1 & .475 & .253 & .006 & 10.988 \\
Secondary & -.673 & 1.861 & .131 & 1 & .718 & .510 & .013 & 19.568 \\
Tertiary & -.369 & 1.953 & .036 & 1 & .850 & .691 & .015 & 31.751 \\
Occupation & & & 1.980 & 4 & .739 & & & \\
Student & 1.300 & .946 & 1.888 & 1 & .169 & 3.668 & .574 & 23.416 \\
Govt. employee & .799 & .965 & .686 & 1 & .408 & 2.224 & .336 & 14.734 \\
Trading & .928 & .900 & 1.065 & 1 & .302 & 2.530 & .434 & 14.753 \\
Self employed & .957 & .883 & 1.176 & 1 & .278 & 2.605 & .462 & 14.688 \\
Constant & .578 & 2.111 & .075 & 1 & .784 & 1.782 & & \\
\hline
\end{tabular}




\section{Predictors: Prison,Age, Sex,Length of jail service, Educational level \& Occupation. Reference category: Prison (Enugu), Age (51+ years), Sex (Male), Length of jail service (8+ years), Education (No school), Occupation (Unemployed) Assessment Score $>42.5$ (expected average) implies professional conduct was assessed good; otherwise is poor}

Table 10a \& b displays a logistic regression on the assessment of professional conduct of healthcare providers. The logistic regression model (logit (assessing the professional conduct to be good $)=0.578-0.260 *($ Ibite-Olo prison $)+1.306 *($ Oji River prison $)-0.511 *(\leq 20$ years $)-$ $0.110 *(21-30$ years $)-0.466 *(31-40$ years $)-0.478 *(41-50$ years $)+0.893^{*}$ gender $-0.297 *(\leq 6$ months $)-0.715 *(7$ months -2 years $)-0.618 *(3-7$ years $)-1.374 *$ (primary) $-0.673 *$ (secondary $)$ $-0.369 *$ (tertiary $)+1.300 *$ (student $)+0.799 *$ (govt. employee $)+0.928 *$ (trading $)+0.957 *$ (self employed)) explained $18.3 \%$ (Nagelkerke $\mathrm{R}^{2}$ ) of the variation in assessment of professional conduct (that is, whether good or poor). It also correctly predicted the professional conduct assessment of $66.4 \%$ of the patients. The omnibus test of model coefficients using the ChiSquare revealed that the model coefficients were not significant, $\chi^{2}(17)=19.394, p=306$. To this effect, the Wald statistic further indicated that the coefficients of all the predictors except that of prison $(\mathrm{p}=.033)$ were not significant: age $(\mathrm{p}=.934)$, sex $(\mathrm{p}=.224)$, length of jail service $(\mathrm{p}=.791)$, educational level $(\mathrm{p}=.621)$ and occupation $(\mathrm{p}=.739)$. This implies that holding other predictors constant, patients classified by their different age groups had the same odds of assessing the professional conduct of healthcare providers to be good; likewise, when classified by their sex, length of jail service, educational level and occupation. However in prison, although, Ibite-Olo prison had the same odds with Enugu prison, $(\mathrm{p}=.705)$; Oji River prison had odds 3.69 times the odds of Enugu prison with 95\% C.I of 1.278-10.651, $(\mathrm{p}=.016)$.

\section{Discussion}

In age, majority of the inmates were between 21-30 years. In length of jail service, Enugu prison and Ibite-Olo prison, and all the prisons put together had more inmates that have served 7 months -2 years, while Oji River prison had more of those that have served 3-7 years. Inmates with secondary education were predominant in Enugu prison and Ibite-Olo prison, and all the prisons put together, while those with tertiary education were predominant in Oji River. In Enugu and Oji River prisons and all the prisons put together, students were most while in IbiteOlo prison, the unemployed were most. Prisoners that have served longer term were associated mostly with Ibite-Olo because the facility is more of a skill acquisition centre before prisoners are eventually released to the community and that facility is exclusively for men. The three prisons are medium facility centres.

The prison patients' assessment of professional conduct of healthcare providers in Enugu shows that, there was an above average compliance to all the listed professional conduct; however, the prominent ones include: observance of the principle of confidentiality, ability to understand the limits of his/her (professional's) practice, timely completion of examination and in response to 
patients' needs. In Ibite-Olo prison, professional conduct such as observance of the principle of informed consent including the right of patients to refuse services, ability to understand the limits of one's' practice and when to seek advice or refer to another professional, ability to make appropriate referrals as the need be in the process of care and examination predominate. However, in observance of clear and appropriate professional boundaries during service provision and observance of equitable treatment regardless of gender and person, there was a very high level of compliance in Ibite-Olo. In Oji-River prison, there was an above average compliance to all the listed professional conduct; however the prominent ones include: observance of clear and appropriate professional boundaries during service provision, ability to understand the limits of one's practice and when to seek advice or refer to another professional, observance of the principle of confidentiality of information acquired through professional contact, ability to act in patients' best interest during contact and service delivery and observance of dignity, privacy and autonomy of patients during treatment/service. In general, for the three prisons put together, four most complied professional conducts were observance of clear and appropriate professional boundaries during service provision, observance of the principle of confidentiality of information acquired through professional contact, observance of equitable treatment regardless of gender and person and timely completion of examination and in response to patients' needs. No professional conduct was complied with below average. The overall assessment of professional conduct of healthcare providers for the different prisons and all the prisons put together shows that in Enugu prison and Oji River prison, the mean assessment score was significantly above average while in Ibite-Olo prison, the mean assessment score was below average though not significant. For all prisons, the mean assessment score was significantly above average. This implies that the professional conduct of healthcare providers in Enugu and Oji-River prisons were above average while that of Ibite-Olo was average. The conduct of healthcare professionals as assessed by the prisoner inmates were in compliance with the professional and Ethical rules for health care professionals in prisons as amply and clearly defined in rules, resolutions, declarations, and recommendations by the United Nations (UN), the Council of Europe, the World Medical Association, the International Council of Nurses, Physicians for Human Rights and Penal Reform International. Accordingly, this finding is supported by [Pont et al., 2012; UN Standard minimum rules, 2011; UN Resolution 37/194, 2011; UN Body of principles for the protection of all persons under any form of detention, 2011; UN Istanbul protocol manual on the effective investigation and documentation, 2011; Council of Europe. Recommendation Rec, 2006; Recommendation R (1987), 1999; the World Medical Association, 2011; the International Council of Nurses, 2011; Physicians for Human Rights, 2011; and Penal Reform International, 2001] of the results from the literature review. This finding is also in compliance with the 7 essential principles of medical care in prison: (free access to medical care, equivalence of prison health care and community health care, confidentiality, patients' consent, preventive health care, humanitarian assistance, complete professional independence and competence) as provided in [Pont et al., 2012].

The comparison between prisons on professional conduct assessment revealed that Oji-River 
prison had highest assessment score, followed by Enugu prison while that of Ibite-Olo prison was least. The comparison revealed a significant difference between the prisons. A post-hoc test indicated that each prison differed from the other on assessment of professionals' conduct. In Enugu, there was an above average compliance to all the listed professional conduct; however, the prominent ones include: observance of the principle of confidentiality, ability to understand the limits of his/her (professional) practice, timely completion of examination and in response to patients' needs. In Ibite-Olo prison, however, the observance of clear and appropriate professional boundaries during service provision and observance of equitable treatment regardless of gender and person had very high level of compliance. In Oji-River prison however, the prominent ones include: observance of clear and appropriate professional boundaries during service provision, ability to understand the limits of one's practice and when to seek advice or refer to another professional, observance of the principle of confidentiality of information acquired through professional contact, ability to act in patients' best interest during contact and service delivery and observance of dignity, privacy and autonomy of patients during treatment/service predominate.

The comparison between age groups on professional conduct assessment shows that in Enugu prison, Ibite-Olo prison and Oji River prison, there was no significant assessment difference between groups, and likewise for all prisons. This implies that the assessment on professional conduct of healthcare providers was the same for the different age groups. Given the no difference in age bracket (majority of the inmates were between 21-30 years) in all the prisons and little if any difference in education, little difference is actually expected in the professionals assessment conduct provided by patient in-mates.

The comparison between sex groups on professional conduct assessment shows that Ibite-Olo and Oji River had no female patient participants. In Enugu prison where there were female prisoner participants; there was no significant assessment difference between males and females, and likewise for all prisons. This implies that the assessment on professional conduct of healthcare providers was the same for both male and female patients.

The professional conduct assessment comparison between patients grouped by the length of jail service reveals that in Enugu, Ibite-Olo and Oji River prisons, there was no significant assessment difference between groups, and likewise for all prisons. This implies that the assessment of professional conduct of healthcare providers was the same for the different length of jail service groups. This result is reinforced by the fact that socio-democratically, the prisons were the same and no wonder there wasn't any difference in the assessment of professional conduct amongst the prisons.

The comparison made between educational levels on professional conduct assessment reveals that in Enugu, Ibite-Olo and Oji River prisons, no significant assessment difference existed between levels. For all prisons put together, there was likewise no significant assessment 
difference between levels. This implies that the educational levels had the same assessment score on professional conduct of healthcare providers. This result is also accounted for by the fact that socio-demographical no difference existed amongst the prisons.

The comparison made between occupational groups on professional conduct assessment show that in Enugu, Ibite-Olo, Oji River prisons, no significant assessment difference existed between groups, and likewise for all prisons put together. This implies that the different occupational groups had the same assessment score on professional conduct of healthcare providers. This result is also accounted for by the fact that socio-demographical no significant difference existed amongst the prisons.

The logistic regression on the assessment of professional conduct of healthcare providers shows that the model (logit (assessing the professional conduct to be good) explained 18.3\% (Nagelkerke $\mathrm{R}^{2}$ ) of the variation in the assessment of professional conduct (that is, whether good or poor). It also correctly predicted the professional conduct assessment of $66.4 \%$ of the patients. The omnibus test of model coefficients using the Chi-Square revealed that the model coefficients were not significant. To this effect, the Wald statistic further indicated that the coefficients of all the predictors except that of prison were not significant: age, length of jail service, educational level and occupation. This implies that holding other predictors constant, patients classified by their different age groups had the same odds of assessing the professional conduct of healthcare providers to be good; likewise, when classified by their sex, length of jail service, educational level and occupation. However in prison, although, Ibite-Olo prison had the same odds with Enugu prison, Oji River prison had odds 3.69 times the odds of Enugu prison. The results of the regression analysis confirm the results as presented above.

\section{Conclusion}

In conclusion, each prison differed from the other on the assessment of professionals' conduct during healthcare service delivery but overall the assessment was on the overage for the three prisons put together. In Enugu, there was an above average compliance to all the listed professional conduct; however, the prominent ones include: observance of the principle of confidentiality, ability to understand the limits of his/her (professional) practice, timely completion of examination and in response to patients' needs. In Ibite-Olo prison, however, the observance of clear and appropriate professional boundaries during service provision and observance of equitable treatment regardless of gender and person had very high levels of compliance. In Oji-River prison however, the prominent ones include: observance of clear and appropriate professional boundaries during service provision, ability to understand the limits of one's practice and when to seek advice or refer to another professional, observance of the principle of confidentiality of information acquired through professional contact, ability to act in patients' best interest during contact and service delivery and observance of dignity, privacy and autonomy of patients during treatment/healthcare service. 


\section{Recommendation and way forward}

Some of the standard ethical and professional rules in prison regarding healthcare provision will require that: Regardless of the circumstances, the ultimate goal of health care staff in prisons must remain the welfare and dignity of the patients. The results of medical examinations and tests undertaken in prison with consent as part of clinical care must be treated with the same respect for confidentiality as is normal under ethics in medical practice [WHO, 2007]. In order to avoid as much as possible any confusion about the role of the doctor, between medical examinations and treatment in the care giving role, and other functions such as providing medical expertise (such as for forensic reports), the doctor should make it clear to the patient at the onset of the consultation that medical secrecy will not apply to the results of any medical examination and tests undertaken for the latter purposes [WHO, 2007]. Regardless of security issues, the health care personnel should have unrestricted access at any time and any place to all detainees, including those under disciplinary measures. Health care staff should under no circumstances participate in enforcing any sanctions against prisoners or in the underlying decision-making process, as this will jeopardize any subsequent doctor-patient relationship. This includes any medical examination to determine if a prisoner is fit to undergo punishment. Medical staff should not carry out any medical acts on prisoners who are restrained (including with handcuffs) [WHO, 2007]. An exception may be considered when the person concerned suffers from an acute mental illness which may create an immediate serious risk for him/ herself or others. Prison doctors should not carry out any body searches or examinations requested by an authority, except in an emergency when no other doctor can be called in or in cases where there is a lack of other qualified health staff. In such cases doctors must explain to the prisoner, before proceeding with the body search, that they are intervening purely as experts, and that their act does not have any diagnostic or therapeutic purpose. Any such body search must have the informed consent of the prisoner. During a hunger strike, doctors must avoid the risk that prisoners, the prison or the judiciary authorities manipulate medical decisions. The extent of the implementation of these principles and rules by our healthcare providers remains questionable especially in the Nigerian context that presents much more severe violations to the principles and ethics guiding healthcare provision in the prison.

We have explored to this point the professional and ethical conduct of healthcare providers in the prison with much success as it concerns the western countries compared to African countries and the Nigerian context in particular. The lack of research and information on how healthcare providers relate to patients both professionally and ethically in prison settings in Nigeria has therefore prompted this study. 


\section{Abbreviations}

United Nations (UN)

The Council of Europe (CE)

World Medical Association (WMA)

The International Council of Nurses (ICN)

Physicians for Human Rights (PHR)

Penal Reform International (PRI)

The standards of the European Committee for Prevention of Torture (SECPT)

\section{Acknowledgements}

We do acknowledge the assistance of the post graduate students who helped in the questionnaire administration and gathering.

\section{Consent to participate}

The prison patient inmates consented to participate in this study verbally. 


\section{References}

American Medical Association. Code of medical ethics. Principles, opinions and reports 2.06 --2.068. Available at: http:// www.ama-assn.org/ama/pub/physicianresources/ medicalethics/code-medicalethics. shtml. Accessed May 24, 2011.

Annas GJ.( 2006). Hunger strikes at Guantanamo-medical ethics and human rights in a "legal black hole.” N Engl J Med; 355(13):1377---1382.

Council of Europe. Recommendation Rec. of the Committee of Ministers to member states on the European Prison Rules 2006. Available at: https://wcd. coe.int/ViewDoc.jsp?id=955747. Accessed May 24, 2011.

Cruzan v. Director, Missouri Department of Health, 497 U.S. 261 (1989). Google Scholar

Enugu State (2004) Enugu State: Poverty Reduction Strategy/State Economic Empowerment Development Strategy PRS/SEEDS 2004-2009. Ministry of Human Development and Poverty Reduction Enugu State.

European Committee for the Prevention of Torture and Inhuman or Degrading Treatment or Punishment (CPT). CPT standards. CPT/Inf/E (2002)1-Rev. 2009. Available at: http://www.cpt.coe. int/en/documents/eng-standards.pdf. Accessed May 24, 2011.

Ezuma N. 2012 Joint Annual Review and 2013 Midterm Review of State Strategic Health Development Plan. Enugu State Report, August.

Frederick R. Parker Jr; Charles J. Paine. (1999). Informed Consent and the Refusal of Medical Treatment in the Correctional Setting. The journal of Law, Medicine and Ethics.; Vol. 27 (3).

Goffman, E. (1961). Asylums: Essays on the social situation of mental patients and other inmates. New York: Anchor Books.

Health in prisons. A WHO guide to the essentials in prison health. World Health Organization, 2007.

Gawande A. (2006). When law and ethics collide — why physicians participate in executions. N Engl J Med.; 354(12): 1221---1229.

Iacopino V, Xenakis SN. Neglect of medical evidence of torture in Guantanamo Bay: a case series. PLoS Med. 2011;8(4):e1001027. 
International Council of Nurses. Nurses' role in the care of detainees and prisoners. Adopted 1998, revised 2006. Available at: http://www.icn.ch/images/ stories/documents/publications/position statements/A13_Nurses Role Detainees_Prisoners.pdf. Accessed May 24, 2011.

Jörg Pont, HeinoStöverand Hans Wolff. (2012). Resolving ethical conflicts in practice and research. Dual loyalty in prison healthcare.American Journal of Public Health | March, Vol 102, No. 3

Lifton RJ. Doctors and torture. N Engl J Med. 2004; 351(5):415---416.

Müller M. Zwangsernährung in derHaft [Forced feeding in detention]. NeueZürcher Zeitung [New Zurich newspaper]. September 9, 2010.

National Commission on Correctional Health Care. NCCHC standards of health services in prison. Available at: http://www.ncchc.org/pubs/index.html. Accessed May 24, 2011.

Natanson v. Kline, 350 P.2d 1093 (Kan. 1960) and In re Yetter, 62 Pa. D. \& C.2d 619, 623, 624 (Pa., Northampton County Ct. 1973).

Ogbonnia Ochonma, Charles Eze, Bartholomew Eze, ChikezieNwankwor. (2016).Patient perceptions of the professional attitudes of Radiographers. British Journal of Healthcare Management; Vol. 22 No 8

Okoli CI and Cleary SM. (2011). Socioeconomic status and barriers to the use of free antiretroviral treatment for HIV/AIDS in Enugu State, south-eastern Nigeria. African Journal of AIDS Research.; 10(2): 149-155.

Onwujekwe O, Onoka C, Uguru N, Tasie N, Uzochukwu B, Eze S, Kirigia J and Petu A. (2010). Preferences for benefit packages for community-based health insurance: an exploratory study in Nigeria. BMC Health Services Research.; 10:162.

Penal Reform International. Making standards work. 2001 Available at: http:// www.penalreform.org/files/man-2001- making-standards-work-en.pdf. Accessed May 24,2011

Physicians for Human Rights and School of Public Health and Primary HealthCare. University of Cape Town, Health Sciences Faculty. Dual loyalty and human rights in health professional practice. Proposed guidelines and institutional mechanisms. March 2002. 
Available at: http://physiciansforhumanrights.org/ library/report-dualloyalty-2006.html. Accessed May 24, 2011.

Pont J, Wool R. EinLeitfadenfür den Gefängnisarzt [A guideline for the prison physician]. Vienna, Austria: Bundesministerium fürJustiz [Federal Ministry of Justice]; 2006. Available at: http://www. fbz-strafvollzug.at/Leitfadenfuerden Gefaengnisarzt.pdf. Accessed May 24, 2011.

Recommendation R (1987)of the Committee of Ministers to Member States on the Ethical and Organisational Aspects of Health Care in Prison. Strasbourg, France: Council of Europe; 1999.

Schloendorff v. Society of New York Hospital, 105 N.E. 92, 93 (N.Y. 1914

SMOH, Enugu State, 2011

Swiss Academy of Medical Sciences. The exercise of medical activities in respect of detained persons. 2002. Available at: http://www.samw.ch/en/Ethics/ Guidelines/Currently-validguidelines. html. Accessed May 24, 2011.

United Nations. Standard minimum rules for the treatment of prisoners. Adopted 1955. Available at: http://www2. ohchr.org/english/law/treatmentprisoners. htm. Accessed May 24, 2011.

United Nations. Resolution 37/194. Principles of medical ethics relevant to the role of health personnel, particularly physicians, in the protection of prisoners and detainees against torture, and other cruel, inhuman or degrading treatment or punishment. Adopted 1982. Available at: http://www.cirp.org/library/ethics/ UN-medical-ethics. Accessed May 24, 2011.

United Nations. Body of principles for the protection of all persons under any form of detention or imprisonment. Adopted 1989. Available at: http://www2. ohcr.org/english/law/bodyprinciples.htm. Accessed May 24, 2011.

United Nations. Istanbul protocol manual on the effective investigation and documentation of torture and other cruel, inhuman or degrading treatment or punishment. 1999. Available at: http://www. ohchr.org/Documents/Publications/ training8Rev1en.pdf. Accessed May 24,2011

Weiskopf, C.S. (2005) . Nurses' experience of caring for inmate patients. Journal of Advanced Nursing 49(4): 336-343. 
White K, Jordens C, Kerridge I. (2014). Contextualising professional ethics: the impact of the prison context on the practices and norms of health care practitioners. Journal of Bioethical Inquiry 11: 333.

World Medical Association. Declarationof Tokyo. Guidelines for physicians concerning torture and other cruel, inhuman or degrading treatment or punishment in relation to detention and imprisonment. 1975, revised Divonee-les-Bains 2005. Available at: http://www.wma.net/e/policy/c18.htm. AccessedMay 24, 2011.

World Medical Association. Declaration on hunger strikers. Malta 1991, revised Marbella 1992. Available at: http://www.wma.net/e/policy/h31.htm. Accessed May 24, 2011.

World Medical Association. Statement on body searches of prisoners. Budapest 1993, revised Divonee-les-Bains 2005. Available at: http://www.wma. net/e/policy/b5.htm. Accessed May 24, 2011.

World Medical Association. Declaration concerning support for medical doctors refusing to participate in, or to condone, the use of torture or other forms of cruel, inhuman or degrading treatment. Hamburg 1997. Available at: http:// www.wma.net/e/policy/c19.htm. Accessed May 24, 2011.

World Medical Association. Resolution on the responsibility of physicians in the denunciation of acts of torture or cruel or inhuman or degrading treatment of which they are aware. Helsinki 2003. Available at: http://www.wma. net/e/policy/t1.htm. Accessed May 24, 2011 